\title{
Sustainable digital transformation of the port equipment management system
}

\author{
Irina Zaychenko ${ }^{1, *}$, Anna Smirnova ${ }^{1}$, Polina Gorshechnikova ${ }^{1}$, and Nikita Piminov ${ }^{2}$ \\ ${ }^{1}$ Peter the Great St. Petersburg Polytechnic University, 29, Polytehnicheskaya str., 195251, St. \\ Petersburg, Russia \\ ${ }^{2}$ LAB University, Finland
}

\begin{abstract}
The subjects of the transport space are developing new tasks, which are due to the accelerated introduction of digital technologies in the economic and social spheres. The article is devoted to the consideration of issues related to the need for digitalization of port equipment and seaports in general. The main advantages and disadvantages of digital transformation are highlighted. Also, the article contains examples of the use of digital technologies in Russian and foreign seaports. Conclusion is made about the need to improve the efficiency of seaports through digital transformation and interaction of subjects within the new digital space.
\end{abstract}

\section{Introduction}

The purpose of this study is to analyze the need for digitalization of port equipment and seaports in general. The relevance of the chosen topic is explained by the structural transformation of the world economy and the transition to the digital economy. Of course, this process affects international trade and, as a result, the management system of port equipment and the seaport generally [1].

To achieve this goal, the following tasks were identified:

1. Analysis of the level of digital transformation in the management of port equipment and seaports in general.

2. Identifying trends in the digitalization of seaports.

3. Highlighting the main advantages and disadvantages of digital transformation.

4. Consideration of examples of digital transformation of seaports and their management systems, in particular.

\section{Materials and Methods}

The transition to the digital economy always entails structural transformation and development within organizations [2,3], this also affects the services they provide and the organizational culture, which allows them to adapt to the digital needs of customers. Organizations are able to meet customer expectations on time, which undoubtedly leads to the strengthening of competitive positions in the market $[4,5]$.

\footnotetext{
* Corresponding author: imz.fem.spbpu@mail.ru
} 
If we talk about the Russian Federation, then today in the country there are various regulatory documents and programs that in one way or another affect the development and digitalization issues, both in general and in particular the digitalization of transport systems, namely seaports. (Table 1).

Table 1. Current regulatory documents regulating the digital transformation of the transport system.

\begin{tabular}{|c|c|}
\hline Document & \begin{tabular}{|c|} 
Goals for digitalization \\
\end{tabular} \\
\hline $\begin{array}{l}\text { Decree of the President of } \\
\text { the Russian Federation of } \\
07.05 .2018 \text { No. } 204 \text { "On } \\
\text { national goals and } \\
\text { strategic objectives of the } \\
\text { development of the } \\
\text { Russian Federation for the } \\
\text { period up to 2024" [6]. }\end{array}$ & $\begin{array}{l}\text { The decree speaks of the need for a breakthrough scientific, } \\
\text { technological and socio-economic development of Russia. The } \\
\text { President calls for ensuring the accelerated introduction of } \\
\text { digital technologies in the economy and social sphere of the } \\
\text { country, including emphasizing the need for digital } \\
\text { transformation of transport infrastructure, especially seaports } \\
\text { through the introduction of digital technologies and platform } \\
\text { solutions. }\end{array}$ \\
\hline $\begin{array}{l}\text { Order of the Government } \\
\text { of the Russian Federation } \\
\text { of } 30.09 .2018 \text { No. 2101-r } \\
\text { "Comprehensive plan for } \\
\text { the modernization and } \\
\text { expansion of the trunk } \\
\text { infrastructure for the } \\
\text { period until 2024" [7] }\end{array}$ & $\begin{array}{l}\text { This document is dedicated to the development of a } \\
\text { comprehensive plan to ensure the development and } \\
\text { modernization of marine and river infrastructure using } \\
\text { advanced technologies. }\end{array}$ \\
\hline $\begin{array}{l}\text { Order of the Government } \\
\text { of the Russian Federation } \\
\text { of } 13.02 .2019 \text {, No. 207-r } \\
\text { "Strategy for the spatial } \\
\text { development of the } \\
\text { Russian Federation for the } \\
\text { period until 2025" [8] }\end{array}$ & $\begin{array}{l}\text { The order of the Government establishes the need for the } \\
\text { development of information and telecommunications } \\
\text { infrastructure by eliminating the "digital inequality" of the } \\
\text { constituent entities of the Russian Federation. Elimination of } \\
\text { such inequality should be carried out by increasing the level of } \\
\text { information and telecommunication connectivity of the } \\
\text { territory of the Russian Federation. According to the } \\
\text { Government of the Russian Federation, this should lead to the } \\
\text { elimination of infrastructural restrictions, as well as increase } \\
\text { the availability and quality of transport infrastructure and } \\
\text { accelerate economic growth and scientific, technological and } \\
\text { innovative development of the Russian Federation. }\end{array}$ \\
\hline $\begin{array}{l}\text { Passport of the national } \\
\text { project "National } \\
\text { Program" Digital } \\
\text { Economy of the Russian } \\
\text { Federation "(approved by } \\
\text { the Presidium of the } \\
\text { Council under the } \\
\text { President of the Russian } \\
\text { Federation for Strategic } \\
\text { Development and } \\
\text { National Projects, } \\
\text { Protocol No. } 7 \text { of } \\
04.06 .2019)[9]\end{array}$ & $\begin{array}{l}\text { The project passport sets the main target indicators that express } \\
\text { the increase in internal costs for the development of the } \\
\text { country's digital economy, this will create a stable and secure } \\
\text { information and telecommunications infrastructure for the fast } \\
\text { transmission, processing and storage of large amounts of data } \\
\text { that are available to organizations and households. }\end{array}$ \\
\hline $\begin{array}{l}\text { Decree of the } \\
\text { Government of the } \\
\text { Russian Federation of } \\
20.12 .2017 \text { No. } 1596 \text { "On } \\
\text { approval of the state } \\
\text { program of the Russian } \\
\text { Federation" Development } \\
\text { of the transport system }\end{array}$ & $\begin{array}{l}\text { The Resolution of the Government of the Russian Federation } \\
\text { sets a goal to increase the competitiveness of the Russian } \\
\text { transport system in the world market of transport services, to } \\
\text { ensure its comprehensive safety and stability. Achieving this } \\
\text { goal is possible through the introduction of new technical } \\
\text { requirements and standards for the operation of transport } \\
\text { infrastructure using digital technologies. It is also necessary to } \\
\text { introduce automated technologies and robotics in transport, in }\end{array}$ \\
\hline
\end{tabular}




\begin{tabular}{|l|l|}
\hline "[10] & $\begin{array}{l}\text { particular, in port equipment to increase the throughput of } \\
\text { Russian seaports. The need to develop information and } \\
\text { computing systems for the automation of technological and } \\
\text { managerial processes of the transport infrastructure in general } \\
\text { is also emphasized. }\end{array}$ \\
\hline $\begin{array}{l}\text { Departmental target } \\
\text { program "Digital Platform } \\
\text { of the Transport Complex } \\
\text { of the Russian }\end{array}$ & $\begin{array}{l}\text { The target program was adopted with the aim of providing } \\
\text { transport infrastructure management bodies with complete } \\
\text { information about the state and progress of the transport } \\
\text { Federation" (approved by } \\
\text { the Ministry of Transport } \\
\text { of Russia on 09/05/2019) } \\
\text { associated with it, as well as its safety and sustainability. The } \\
\text { program is also aimed at providing data on the demand for } \\
\text { transport services and making forecasts for demand, and the } \\
\text { level of information awareness of the population and safety } \\
\text { should also increase. Achieving a high level of the above } \\
\text { parameters is possible due to the automation and information } \\
\text { and analytical support of the transport complex management } \\
\text { processes, as well as the improvement and maintenance of the } \\
\text { functioning of the information security system of the transport } \\
\text { system, taking into account changes in legislation. }\end{array}$ \\
\hline
\end{tabular}

The considered normative legal acts testify to the relevance of the digital transformation of the transport system, in particular, seaports on the territory of the Russian Federation.

The need for digital transformation of the transport system creates a number of new challenges for all subjects of the transport system. However, it is worth noting that digitalization will bring both advantages and disadvantages to the system.

The main ones are presented below, in table 2.

Table 2. The main advantages and disadvantages of the digital transformation of the transport system.

\begin{tabular}{|c|c|}
\hline Benefits & Disadvantages \\
\hline Saving resources & Job cuts \\
\hline Business process automation & Risk of cyberattacks \\
\hline Personalization for clients & Deficiency of highly qualified personnel \\
\hline Ease of transactions & Possible technical equipment failures \\
\hline Analysis and forecasting capability & $\begin{array}{l}\text { A small number of in-house developments } \\
\text { in automation (typical for Russia). }\end{array}$ \\
\hline Electronic payments & \\
\hline Growth of qualified personnel. & \\
\hline
\end{tabular}

Despite the fact that the negative consequences may be significant for the further successful functioning of the transport system, the implementation of digital management in ports is an important issue in the processes of globalization of production and integration into the world economy.

\section{Results}

\subsection{Analysis of the work of the seaports in Russian Federation}

Russian ports play an important role in the country's foreign trade and economic development. Up to $80 \%$ of cargo from the entire external trade turnover of Russia passes through sea terminals.

The main feature of the functioning of Russian seaports is their uneven workload in the transshipment of goods across sea basins. This can be explained by several factors: geography and peculiarities of logistic routes. For example, most of the coal is transshipped in the ports of the Far East, in the ports of the Baltic basin, cargo in containers and mineral 
fertilizers are usually transshipped, and in the ports of the Azov-Black Sea basin - grain and metals.

If we evaluate the cargo turnover that passes through Russian ports, then by the end of 2019 it amounted to 840.3 million tons. Compared to 2018, this figure increased by $2.9 \%$, but if compared with 2003, the cargo turnover increased almost 3 times. The dynamics of the cargo turnover of the seaports of the Russian Federation can be estimated in Figure 1.

Figure 1 shows that the upward trend in freight turnover is stable and has been observed for a long time. A similar dynamic is observed if we consider the cargo turnover for each basin, this can be seen in Figure 2.

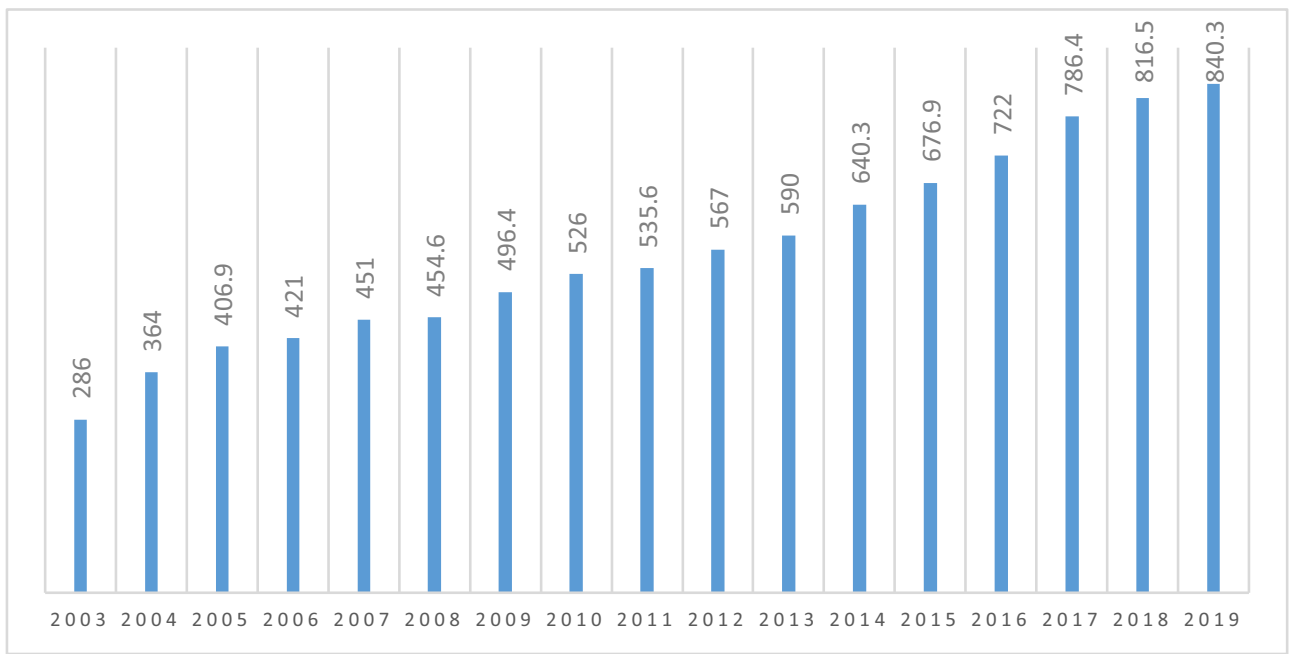

Fig. 1. Dynamics of cargo turnover of seaports of the Russian Federation [10].

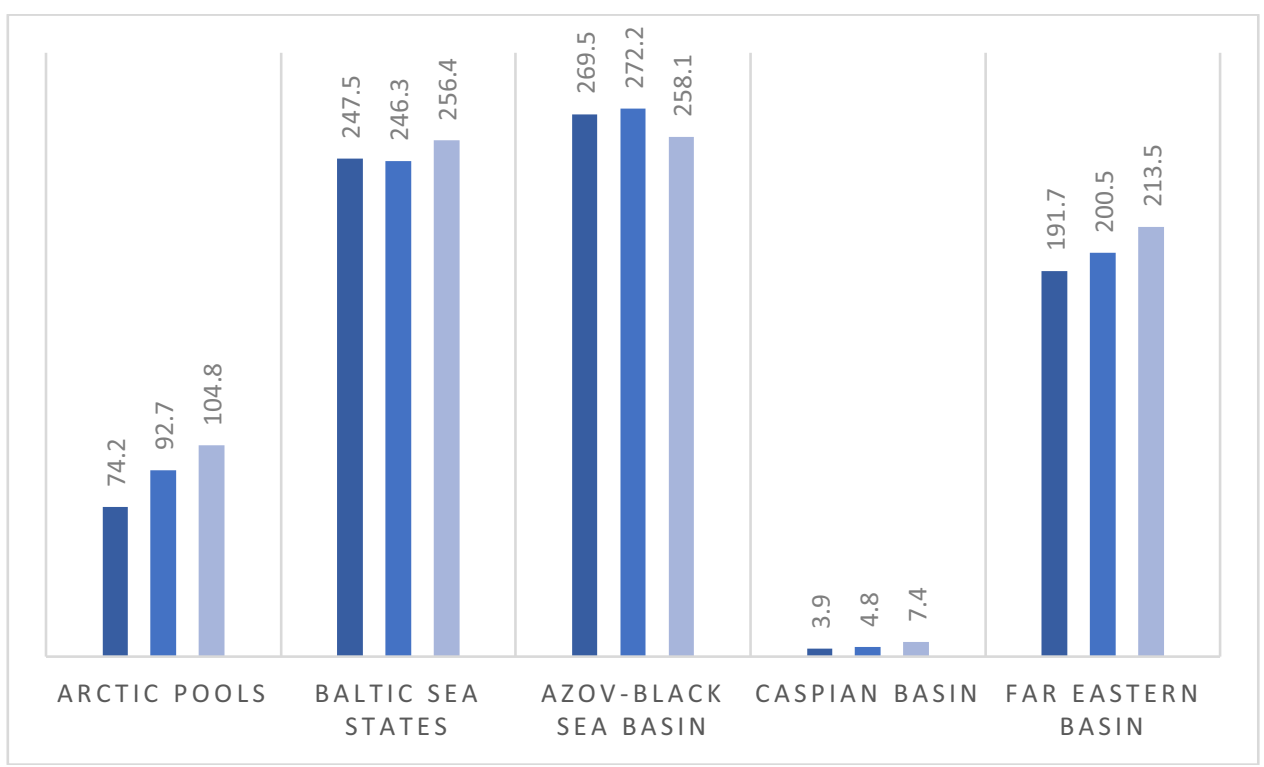

Fig. 2. Dynamics of cargo turnover in ports by basins of the Russian Federation [12].

According to the Association of Commercial Sea Ports, it can be concluded that the dynamics of the turnover of Russian seaports in recent years has shown a stable steady growth. 
According to experts [13], these trends will continue until 2030. For 2020, the forecast for cargo turnover is 884 million tons, for 2025 - 995 million tons, for 2030 - 1129 million tons. This volume can be realized due to several factors, including through the use of digital solutions in seaports.

\subsection{Analysis of the level of digitalization in foreign ports}

If we talk about history, the beginning of the process of digital transformation of seaports in the world dates back to 1993. This year, for the first time, unmanned vehicles were used to handle containers in the port of Rotterdam. The work was carried out with the help of RMG and AGV drones, they were used for horizontal handling of containers [14].

Today, the port of Rotterdam is still considered one of the leading European ports, including through the use of digital solutions. For example, a large-scale digital transformation was carried out in this port, the transformation program was called "the smart port in the world". The goal of this digitalization is to accept autonomous connected cargo ships in 2025, that is, to create a digital twin of the port that will cover the entire 42 $\mathrm{km}$ long port area. The twin is an exact digital replica of port operations. The similarity reaches $100 \%$. With the help of a double, you can track the movement of ships, all infrastructure, geographic data on ships and their depth, and also take into account weather conditions $[15,16]$.

Table 3, based on sources [17-23], presents the experience of other foreign ports in the use of digital technologies.

Table 3. Application of digital solutions in seaports.

\begin{tabular}{|l|l|}
\hline \multicolumn{1}{|c|}{ Port } & \multicolumn{1}{c|}{ Technologies used } \\
\hline Rotterdam & $\begin{array}{l}\text { This port actively uses Internet of Things, namely IoT sensors, as well as } \\
\text { augmented intelligence technologies and intelligent data to assess the } \\
\text { availability of the berth, weather conditions, as well as to work out various } \\
\text { scenarios and record incoming and outgoing ships. On the basis of the port } \\
\text { under consideration, there is also a research center Rotterdam Additive } \\
\text { Manufaturing LAB. It is the world's first 3D printing field laboratory that } \\
\text { fulfills specific requests for metal ship parts. }\end{array}$ \\
\hline Hamburg & $\begin{array}{l}\text { The port of Hamburg is digitally renowned for its navigation system. This } \\
\text { system allows participants to use personalized navigation, having } \\
\text { information about the traffic situation in the port, the closure of bridges and } \\
\text { parking. } \\
\text { The port of Hamburg also has a system called the "smart railroad point". } \\
\text { Sensors are installed on the port territory, which allow analyzing the } \\
\text { congestion of the port railway. The installed sensors also help to analyze the } \\
\text { condition of the main working intersections and take into account their wear. } \\
\text { This data further helps to avoid possible downtime. }\end{array}$ \\
\hline Tilbury & $\begin{array}{l}\text { The Port of Tilbury is known for its application that has been designed } \\
\text { specifically for the terminal carriers. The main purpose of the application is } \\
\text { online vehicle booking. In addition to this function, carriers can place orders } \\
\text { and check the status of containers remotely using their smartphone. }\end{array}$ \\
\hline Montreal & $\begin{array}{l}\text { The Trucking Portal application has been created specifically for this port } \\
\text { and has been designed to reduce pollution and increase port productivity. In } \\
\text { addition to solving environmental issues, the application allows you to } \\
\text { optimize the routes of loaders by reducing traffic jams that can form at the } \\
\text { entrance and exit of the loading terminals. }\end{array}$ \\
\hline Qingdao & $\begin{array}{l}\text { Qingdao Port can be considered a port, with a fully automated container } \\
\text { terminal. } \\
\text { The terminal has laser scanners and a container positioning system, with their } \\
\text { help, you can install, secure and transfer containers to the trucks of drivers. }\end{array}$ \\
\hline
\end{tabular}




\begin{tabular}{|l|l|}
\hline & $\begin{array}{l}\text { In addition to this system, the port is also equipped with an automated } \\
\text { planning system, an automated vessel mooring system, as well as fully } \\
\text { automated container delivery and an installed unmanned intelligent gate } \\
\text { system. }\end{array}$ \\
\hline Long beach & $\begin{array}{l}\text { Long Beach - equipped with a fully automated terminal. A special feature of } \\
\text { this port are mega cranes with a huge lifting capacity, which are capable of } \\
\text { handling several containers at once and serving large ships. The port is also } \\
\text { equipped with automatic gantry trolleys and stacking cranes, with a fully } \\
\text { automated system for automatically lowering and lifting containers on the } \\
\text { chassis, the system can be controlled remotely from a centralized control } \\
\text { room. For container transportation in the port of Long Beach, automated } \\
\text { intermodal station cranes are provided, which are designed to service trains } \\
\text { at the railway station. }\end{array}$ \\
\hline
\end{tabular}

As a result of the analysis of the activities of seaports, which have already resorted to the digital transformation of their activities, it can be concluded that the use of digital solutions in the port allows:

- to increase the volume and efficiency of shipment of goods;

- reduce the time the vessel is in the parking lot;

- to increase the number of accepted ships in the port on a daily basis;

- to reduce the level of load on transport routes;

- to double the port capacity, while the port area will remain unchanged;

- to improve the efficiency of the personnel;

- track the location of the cargo at any time.

\section{Discussion}

Today, the issues of the competitiveness of the work of seaports for the Russian Federation are very relevant. Including increasing the efficiency of the port through the use of digital technologies, which would increase the level of port innovation. That is why a number of digital solutions are already being used in seaports, such as:

1. Electronic document flow greatly simplifies and accelerates the port's activities with contractors. In addition to this, downtime and costs are reduced by eliminating paper media and transferring all documentation to electronic format. Today, electronic document management is actively used in ports: JSC Rosterminalugol, OO NUTEP, JSC First Container Terminal, JSC Petrolesport, JSC Noaoroslesexport, PJSC Vladivostok Commercial Sea Port.

2. In the ports of the Russian Federation, the concept of "lean production" is actively used, for example, in JSC "Rosterminalugol". The purpose of the concept is to optimize processes. It can be achieved by identifying and eliminating hidden losses, as well as providing a high-quality management infrastructure and changing the mindset of employees.

3. The system of operational management in the activities of container terminals. Such a system is actively used in LLC NUTEP, PJSC Novorossiysk Commercial Sea Port, LLC Vladivostok Container Terminal, JSC First Container Terminal, JSC Ust-Luga Container Terminal. The purpose of the system is to improve the efficiency of container handling through the management of personnel and equipment at the container terminal in real time.

4. JSC "Rosterminalugol", JSC "Vostochny Port" use automated control systems in the activities of the seaport and the railway. Thanks to automation, it is possible to feed, unload, send wagons to the terminal in automatic mode.

5. Automated systems of interaction between seaports and federal executive authorities are used in the KPS "Portal" Sea Port". This is a system that operates on the basis of the principles and mechanisms of a "single window", provides electronic interaction of all 
participants in the process of registration of goods and vehicles at sea checkpoints in order to create favorable conditions for accelerating goods turnover across the customs border of the Eurasian Economic Union, reducing the time for customs clearance. operations, improving the efficiency of customs control.

6. Service system for ships "Digital Port" (joint development of JSC "Infotech Baltic" and ICONIC). The system is based on the technology of maintaining distributed registers of accounting and certification of rights, which makes it possible to transfer the document flow of a vessel with a port into electronic form, thereby reducing and / or reducing: production loads on participants in port activities; working hours of port agents; processing time of the vessel; controversial issues in the activities of participants in port activities.

7. Systems for interaction with information systems of sea vessels and with trade portals on the principle of one window, is used in the terminals in Ust-Luga and Nakhodka.

8. Specialized systems such as security systems, number recognition systems for containers, cars and railway platforms and other systems.

Having studied Russian innovations in the field of digital transformation by a seaport, we can conclude that certain types of automation and information technologies prevail over complex digital transformation. This is most likely due to the inconsistency with regulatory regulation and the problem of import substitution of digital technologies.

\subsection{Recommendations for digital transformation of port equipment in Russia}

The process of digital transformation of port equipment can consist of the following stages, which will ensure the sustainable development of the management system of seaports during the digitalization period:

- Carrying out diagnostics of business processes within the functioning of the port management system.

- Collecting data on the current level of digitalization of port equipment.

- Based on the collected data, assess the level of digitalization and information security of this data.

- Identification of bottlenecks and priority areas for development and digital transformation.

- Development of a model for the transition of the seaport from analog to digital basis for the implementation of activities.

- It is necessary to form a roadmap. Determine the timing and materials required for digital transformation.

- Implementation of the roadmap.

- Analysis of the results obtained.

- Determine the level of digital transformation of the port, conduct a comparative analysis. If positive, consider scaling.

\section{Conclusions}

The purpose of this study was to analyze the need for digitalization of port equipment and seaports in general.

In the course of achieving this goal, the following tasks were identified:

1. Analysis of the level of digital transformation of management of port equipment and seaports in general.

2. Identified trends in the digitalization of seaports.

3. Highlighted the main advantages and disadvantages of digital transformation.

4. The most striking examples of digital transformation of seaports and their management systems, in particular, are considered. 
In conclusion, I would like to note that the prospects for the development of seaports in Russia are the creation of "smart ports" based on the use of various digital solutions, and this will create an absolutely new logistics.

It should be borne in mind that the selection and implementation of digital solutions in the activities of seaports is a transformational and complex process that can be either destructive or transitional. The impact of the transition will depend on the nature of the business processes resulting from technology adaptation in the sector.

The main thing is to take into account issues related to the digital interaction of seaports with other subjects of the transport space in order to ensure the synchronization of their activities in various aspects: organizational, personnel, legal, financial, technological, security and others.

\section{References}

1. How blockchain technology could change our lives In-depth Analysis (European Union, Brussels, 2017)

2. A. Rudskoy, A. Borovkov, P. Romanov, O. Kolosova, IOP Conference Series: Materials Science and Engineering (2019) https://doi.org/10.1088/1757899X/497/1/012088

3. I. Ilin, S. Shirokova, A. Lepekhin, E3S Web of Conferences 33, 03007 (2018) DOI: $10.1051 / \mathrm{e} 3$ sconf/20183303007

4. Paperless Trading: How Does It Impact the Trade System? (WEF, 2017)

5. V.P. Kupriyanovsky et al., International Journal of Open Information Technologies 6(1), 46-91 (2018)

6. The decree of the President of the Russian Federation of 07.05.2018 No. 204, http://publication.pravo.gov.ru/Document/View/0001201805070038

7. Order of the Government of the Russian Federation of 30.09.2018 N 2101-r (2020) http://www.consultant.ru/document/cons_doc_LAW_308743/

8. Decree of the Government of the Russian Federation No. 207-r of February 13, 2019 On the Approval of the Spatial Development Strategy of the Russian Federation for the period up to 2025, https://www.garant.ru/products/ipo/prime/doc/72074066/

9. Passport of the national project "National Program" Digital Economy of the Russian Federation" (2019) http://www.consultant.ru/document/cons_doc_LAW_328854/

10. The resolution of the RF Government dated 20.12.2017, No. 1596, https://www.garant.ru/products/ipo/prime/doc/71743998/

11. Departmental target program "Digital platform of the transport complex of the Russian Federation" (2019) https://legalacts.ru/doc/vedomstvennaja-tselevaja-programmatsifrovaja-platforma-transportnogo-kompleksa-rossiiskoi-federatsii//

12. V. Kupriyanovsky et al., International Journal of Open Information Technologies 4(8), 36-42 (2016)

13. A. García-Herrero, K.C. Kwok, L. Xiangdong, T. Summers, Z. Yansheng, EU-China Economic Relations to 2025 (The Royal Institute of International Affairs, 2017)

14. V.P. Kupriyanovsky et al., International Journal of Open Information Technologies 5(3), 79-99 (2017)

15. V. Kupriyanovsky et al., International Journal of Open Information Technologies 5(2), 64-84 (2017) 
16. V.P. Kupriyanovsky et al., Modern information technologies and IT education 13(1), 58-80 (2017)

17. A. Shichkov, V. Gluhov, IOP Conference Series: Materials Science and Engineering (2019) https://doi.org/10.1088/1757-899X/497/1/012093 .

18. D. Zamolodchikov et al., International Journal of Open Information Technologies 5(3), 100-116 (2017)

19. I.V. Ilin, D.D. Bolobonov, A.K. Frolov, Proceedings of the 33rd International Business Information Management Association Conference, IBIMA 2019: Education Excellence and Innovation Management through Vision 2020, 5092-5102 (2019)

20. V. Kupriyanovsky et al., International Journal of Open Information Technologies 5(3), 117-132 (2017)

21. S. Maydanova, I. Ilin, A. Lepekhin, Proceedings of the 33rd International Business Information Management Association Conference, IBIMA 2019: Education Excellence and Innovation Management through Vision 2020, 5103-5111 (2019)

22. V. Orlova, I. Ilin, S. Shirokova, MATEC Web of Conferences 193 (2018) 